\title{
The Role of Religious Commitment, Religious Self-Identity on Consumer's Willingness to Pay for A Halal Product
}

Rahma Elsitasari ${ }^{*}$,

Asmai Ishak ${ }^{2}$

1,2Faculty of Business and Economics, Universitas Islam Indonesia, Yogyakarta, Indonesia

\begin{tabular}{ll}
\hline ARTICLE INFO & ABSTRACT \\
\hline ISSN: 2723-1097 & $\begin{array}{l}\text { This research aims to analyze consumer's willingness to pay toward halal products } \\
\text { through the role of religious commitment, religious self-identity, using the theory } \\
\text { of planned behavior. This study examines the willingness to pay consumers based } \\
\text { on the consumption experiences of well-known foreign franchise restaurants in }\end{array}$ \\
$\begin{array}{l}\text { Indonesia. The data was collected through } 250 \text { Muslim students in Yogyakarta. } \\
\text { theory of planned }\end{array}$ & $\begin{array}{l}\text { The survey was filled by Google form. Data were analyzed using structural } \\
\text { behovior; religious } \\
\text { commitment; halal } \\
\text { product. }\end{array}$ \\
$\begin{array}{l}\text { equation modeling, employing the partial least square method (PLS). Findings of } \\
\text { on the willingness to pay for the halal product, while the perceived behavioral } \\
\text { control, the subjective norm, and the religious commitment have a positive and } \\
\text { significant effect on the willingness to pay. Additionally, religious commitment has } \\
\text { a positive and significant influence on the attitude, and on the religious self- } \\
\text { identity. The practical implication of this study suggests the marketers should } \\
\text { understand those variables that influence consumers' willingness to pay for halal- } \\
\text { certified products from foreign franchise restaurants, namely the subjective norms, } \\
\text { the perceived behavioral control, and the religious commitment. }\end{array}$
\end{tabular}

\section{Introduction}

The halal industry has rapidly grown in line with the increasing Muslim population in the world. The industry has developed into a lifestyle that offers halal travel, hospitality service, and fashion. The change of Muslim consumer mindset and cultural trends are the triggers (Afrief.org, 2019). A halal market is emerging as one of the most profitable and influential markets in the food business. Muslim spending on foods and beverages was around USD 1,4 trillion in 2018 and estimate to reach USD 2 trillion by 2024. State of the Global Islamic Economy Report reveals that Indonesia will become the country with the largest halal consumption market with an expenditure of 173 billion (Salaamgateaway.com, 2019).

Muslim's encouragement for consuming halal food is pushed not only by keeping up with lifestyle trends but also by religious obedience. The willingness obeying to religious orders by only consuming halal food can create a consumer's

Journal of Business and Management Review Vol. 2 No. 42021 Page 289- 302

DOI: $10.47153 /$ jbmr24.1232021

*Corresponding Author

Email address: rahmaelsitasari.qsa@gmail.com 
involvement and affect the consumer's buying decision in choosing the desired product. So that, a halal certificate is necessary for Muslim consumers. In Indonesia, certified halal products in public is only $10 \%$. Until 2018, 688.615 products, 55.626 companies got the halal license, and the number of halal certificate holders was 65.116 (Ekonomibisnis, 2019)

The food product in Indonesia is not only from the local product but also from a foreign product such as franchise restaurants. Foreign franchises control $35 \%$ of the market share, meanwhile, $65 \%$ by local brands. However, the global franchise still dominates the number of outlets (Kontan.co.id, 2019). The well-known Global franchises in Indonesia are McDonald's, KFC, Pizza Hut. They already have halalcertified products. On the other hand, Indonesian consumers are reluctant to ask about the halalness of a product or food sold by a street seller or at a shopping center. Consumers only appraise halal products in one aspect, namely pork and its derivatives, although halal is not only about it (Republika.com, 2019).

The halal guarantee on product packaging is one of the factors that influence buying interest (Syahputra, 2014). People prefer certified halal products rather than not and are willing to pay a higher price for them (Arni et al., 2018).

Ngah et al. (2020) conduct a study of factors that influencing the consumers' willingness to pay the halal transportation cost. These factors are based on the theory of planned behavior. The theory of planned behavior states that three main points determine a person's behavior which are an attitude, subjective norm and, perceived behavioral control (Ajzen, 2007). Besides, other factors that influence Muslim consumer behavior which is religious self-identity and religious commitment. Iranmanesh et al. (2020) explain that religious commitment is a strong predictor for willingness to pay halal products and, religious self-identity influences positively that.

According to that explanation, this research focuses on consumer behavior toward a willingness to pay halal-certified products using the theory of planned behavior that consists of attitude, subjective norm, perceived behavioral control, and adding factors which are religious self-identity and religious commitment. In other words, this research aims to determine the effect of the theory of planned behavior, religious commitment, and religious self-identity on consumers' willingness to pay halal products. Now, the research's object is Muslim consumers on global franchises namely McDonald's, KFC and, Pizza Hut.

\section{Literature Review}

\section{Halal Term}

Halal is a term that refers to Al Quran that means something that is allowed. This term is primary knowledge for Muslims and is considered a necessity to know it. Therefore, Muslims must be able to identify between halal and haram. The halal term 
is used on food, meat, cosmetic, personal care products, food and beverage ingredients, and food contact material (Lada, 2009).

\section{Theory of Planned Behavior}

The theory of planned behavior is similar to other cognitive decision-making models in the underlying assumption that individuals make decisions rationally and systematically through available information (Ajzen, 1991). According to the theory of planned behavior, beliefs about attitude, control, and norm influence behavior, and intention plays a role in mediating it (Kautonen, 2015). The objectives and benefits are to forecast and understand motivational influences to non-enforced behavior, to identify how and where to direct strategies for behavioral change and to explain important aspects of human behaviors. This study uses the theory of planned behavior as the basis of the research model cause this theory can identify the factors that affect individual willingness to pay halal products.

\section{Willingness to Pay}

Willingness to pay refers to the economic term, price, or maximum amount a customer is willing to a particular item (Jedidi and Zhang, 2002 on Fathi, 2016). Zeithaml et al. (2016) on Aisyah (2014) explain that consumer behavioral intention can be measured by five things, (1) Loyalty; the willingness of a consumer to buy a product. (2) Switch; reluctance to switch to another product. (3) Internal response; willingness to give positive feedback to the company (owner, management area, or employee). (5) External response; readiness to give product reference to family, friend, or associate. The level of consumer perception of a product also affects the level of consumer willingness to pay for a product ( $\underline{\text { Zhang, 2020) }}$

\section{Attitude}

According to Hawkins and Mothersbaugh (2016), attitude is a perpetual organization of motivational, emotional, perceptual, and cognitive processes concerning aspects of the environment. Chen and Tung (2014) describe attitude as a result of consumer psychological emotion manifested in positive behavior if the assessment is positive or vice versa. Soesilowati dan Yuliana (2013) clarify that region with the Muslim's minority population has a higher attitude in consuming halal food than residents in Muslim's majority areas whose tend to be more tolerant for buying an uncertified-halal product. It might be caused by the limitation of the halal-certified product. Kadengkan and Linarti (2020), Kim et al. (2018) explain that attitude has a significant impact on consumer intention to buy a halal product. Hultman et al. (2015) and Iranmanesh et al. (2020) reveal that attitude has a positive and significant impact on willingness to pay whereas, Afandi et al. (2014) state that attitude has a negative and insignificant effect on a consumer buying decision. Kashif et al. (2017) show that attitude does not have a significant influence on the intention to behave ethically (taking decisions ethically) in the workspace. 


\section{Subjective Norm}

Subjective norm is a viewpoint of other people that is important to the individual and can influence decision making such as family, relatives, colleagues, friends, and business partner (Verma and Chandra, 2017). The research by Kumar and Smith (2017) reveal that subjective norm has a positive effect on the intention to buy local food. Huang et al. (2015) state that interpersonal others will affect subjective norms to the willingness to pay. Meanwhile, Iranmanesh et al. (2020) explain that subjective norm does not influence willingness to pay because the halal label has given enough information about the ingredient and production process of food, so the consumer does not depend on other people's opinion while making a decision. Wong et al. (2018) clarify that subjective norm does not predict significantly on intention to buy.

\section{Perceived Behavioral Control}

Perceived Behavioral Control refers to perception about easy or difficult people in doing a particular behavior (Ajzen, 1991). The research conducted by Huang et al. (2015) shows that perceived behavioral control has a positive and significant relation with visitor's willingness to pay when a visit to a public park. Cahyono (2017) on Efendi et al. (2020) research and Efendi et al. (2020) find that perceived behavioral control has a positive and significant effect on the intention to buy a halal product. Meanwhile, the research by Wong (2018) explains that perceived behavioral control does not predict a desire to buy significantly. Iranmanesh et al. (2020) find a similar result that shows perceived behavioral control does not influence willingness to pay a halal-labeled product.

\section{Religious Self-Identity}

The research conducted by Ali et al. (2017) defines self-identity as a relatively persistent characteristic that other people assume as their identity and frequently similar to self-concept. Religious self-identity is an individual's rigor in following his religious guidelines. Although someone sometimes does not fully implement Islamic rules and is more influenced by the community ( Shahzad, 2020). The study conducted by Vanany et al. (2018) and Shahzad (2020) explain that religious self-identity can significantly predict the consumption of halal food in Indonesia. Iranmanesh et al. (2020) state that religious self-identity influences positively consumer's willingness to pay for a halal product. Contrary to that research, Khibran (2019) finds Muslim's selfidentity hurts intention to buy beef at the traditional market because consuming halal food is familiar, and people assume the seller is Muslim.

\section{Religious Commitment}

Hidayat and Ahmad (2015) explain that religious commitment has merits that are a strong desire to carry out religious rules, faith, and acceptance of faith values. Larasati et al. (2018) state that the more someone deepens his faith and implement to 
himself identity, the more it affects his worth and behavior. The previous research conducted by Rahman et al. (2015), Larasati et al. (2018), and Iranmanesh et al. (2020) reveal that religiosity has a positive and significant impact on consumer's attitudes toward a halal product. Contrary to the result above, Maharani and Silvia (2019) find that religiosity has a positive effect but insignificant.

Furthermore, according to Weaver and Agle (2002), if someone internalizes faith to social interactions continuously, religion will affect self-identity as a believer. Religious self-identity is formed by the internalization of the role of faith and its effect as the basis of moral life values (Chen, 2017). The level of religiosity will decide the degree of a person's apprehension for consuming halal food (Vanany et al., 2018). Based on previous research of Iranmanesh et al. (2020), religious commitment predicts its effect on religious self-identity strongly.

Those who have a fit commitment to faith in attitude and behavior afford to make consistent decisions that fit their religion. Religiosity affects Muslim consumer's like or dislike, and they consider buying a product if the product suits religious rules (Newaz, 2016). Ahmed et al. (2018) explain in their research that religiosity has a positive and significant impact on willingness to pay a halal product. Empirical research conducted by Fatya et al. (2018) and Garg (2018) show that religiosity influences buying intention and attitude toward halal food and brand. Religious commitment is a strong predictor of willingness to pay a halal product. Contrast with previous research, Ngah et al. (2020) show that religiosity significantly does not influence willingness to pay.

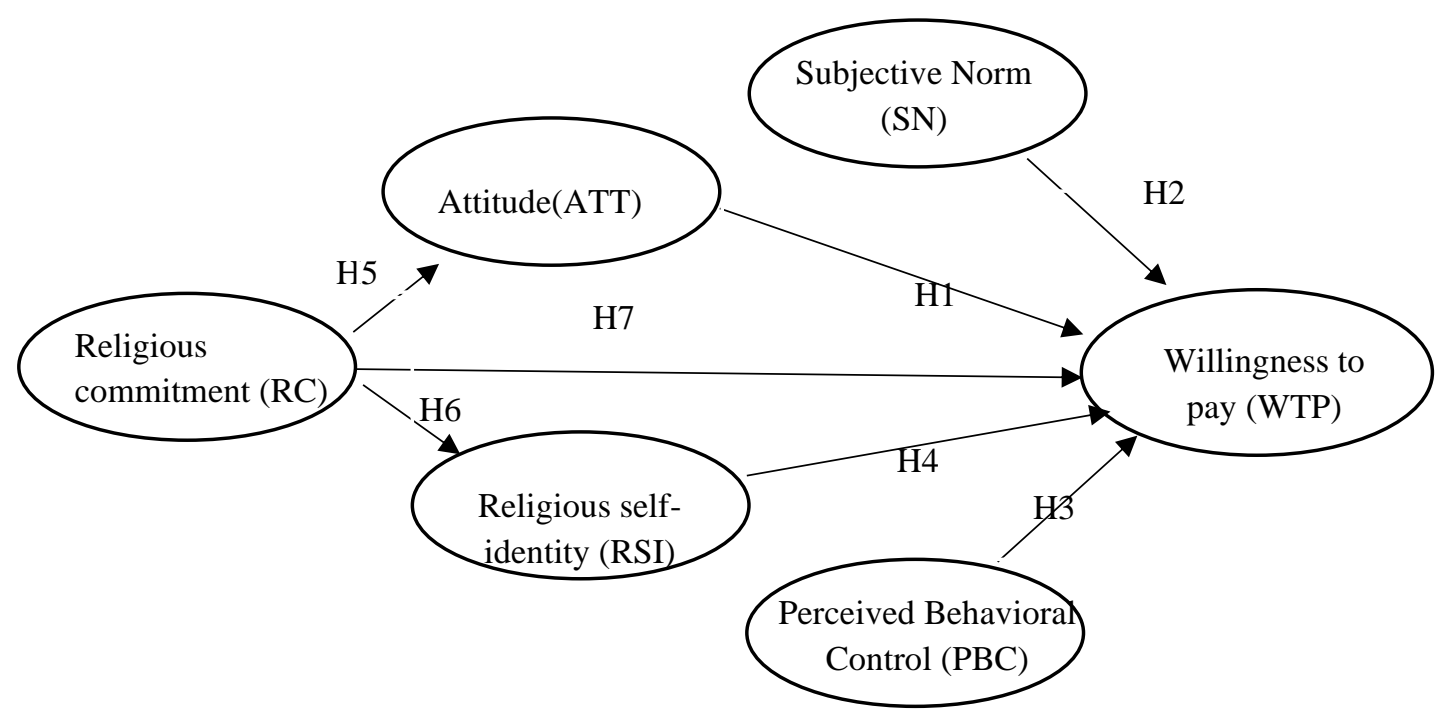

Picture 1. Research Model

\section{Method}


The population of this research comes from Muslim students at Yogyakarta, and the respondent is 250 . The data comes from an online survey using google forms. The questionnaire used a 1-6 Likert scale measurement. The collecting sample method is non-probability with purposive sampling; collecting the sample from a consumer that fills requirements and is willing to filling in the questionnaire. Partial least squaresstructural equation modeling is used to analyze the data, and the program is running by SmartPLS. PLS is used in data analysis because it does not require data to be distributed normally. Moreover, PLS is a powerful analysis method cause, it does not require many assumptions or requirements (Syahrir et al., 2020). This PLS' analysis data consist of two steps, which are measurement model and structural measurement. The structural model is evaluated by observing significant relation between each construct or variable through the coefficient path, which describes the strength of the relationship between constructs. The valid indicator is if $T$ value $\geq 1.96$, or P-value $\leq 0.05$ (

\section{Result and Discussion}

Picture 2: Image of research model with PLS

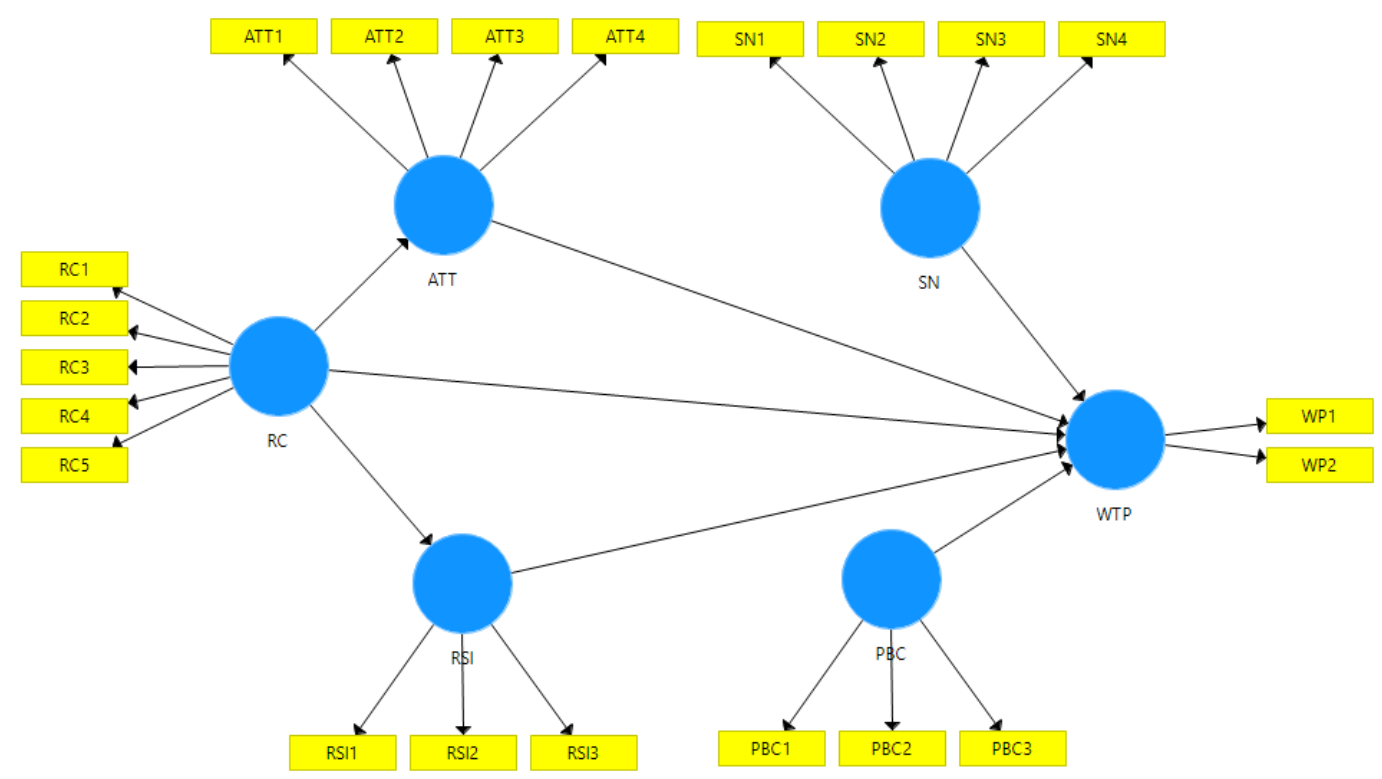

The measurement model was evaluated by assessing convergent validity and discriminant validity that show results on loading factors $\geq 0.7$, which means all indicators are valid for measuring construct. Cronbach alpha and composite reliability on all variables are $\geq 0.7$, which means all variables have become the fit measurement, and all questions used to size every construct has good reliability. The values of average variance extracted (AVE) of all variables were above 0.50 . That finding indicates an opportune convergent validity. Discriminant validity was evaluated by two methods. The first method is to rate the cross-loading values. 
Table 1. Cross Loading

\begin{tabular}{lllllll}
\hline & ATT & PBC & RC & RSI & SN & WTP \\
\hline ATT1 & $\mathbf{0 . 9 5 6}$ & 0.576 & 0.806 & 0.889 & 0.843 & 0.687 \\
ATT2 & $\mathbf{0 . 9 0 5}$ & 0.644 & 0.704 & 0.745 & 0.687 & 0.662 \\
ATT3 & $\mathbf{0 . 9 0 3}$ & 0.456 & 0.692 & 0.841 & 0.840 & 0.625 \\
ATT4 & $\mathbf{0 . 9 6 4}$ & 0.605 & 0.748 & 0.827 & 0.777 & 0.672 \\
PBC1 & 0.580 & $\mathbf{0 . 8 1 6}$ & 0.526 & 0.640 & 0.484 & 0.594 \\
PBC2 & 0.550 & $\mathbf{0 . 8 0 4}$ & 0.533 & 0.563 & 0.469 & 0.567 \\
PBC3 & 0.348 & $\mathbf{0 . 8 1 5}$ & 0.442 & 0.379 & 0.282 & 0.509 \\
RC1 & 0.683 & 0.596 & $\mathbf{0 . 8 4 9}$ & 0.710 & 0.555 & 0.600 \\
RC2 & 0.594 & 0.428 & $\mathbf{0 . 8 3 6}$ & 0.660 & 0.637 & 0.641 \\
RC3 & 0.680 & 0.552 & $\mathbf{0 . 9 1 1}$ & 0.705 & 0.618 & 0.672 \\
RC4 & 0.769 & 0.635 & $\mathbf{0 . 8 3 7}$ & 0.699 & 0.612 & 0.663 \\
RC5 & 0.699 & 0.466 & $\mathbf{0 . 8 9 8}$ & 0.750 & 0.719 & 0.707 \\
RSI1 & 0.838 & 0.600 & 0.725 & $\mathbf{0 . 9 1 2}$ & 0.778 & 0.677 \\
RSI2 & 0.740 & 0.612 & 0.696 & $\mathbf{0 . 8 5 7}$ & 0.639 & 0.579 \\
RSI3 & 0.826 & 0.581 & 0.790 & $\mathbf{0 . 9 4 6}$ & 0.781 & 0.635 \\
SNI1 & 0.847 & 0.425 & 0.663 & 0.835 & $\mathbf{0 . 8 7 0}$ & 0.589 \\
SNI2 & 0.672 & 0.387 & 0.565 & 0.636 & $\mathbf{0 . 8 1 3}$ & 0.559 \\
SNI3 & 0.564 & 0.304 & 0.486 & 0.539 & $\mathbf{0 . 8 2 4}$ & 0.493 \\
SNI4 & 0.779 & 0.589 & 0.731 & 0.744 & $\mathbf{0 . 9 1 4}$ & 0.755 \\
WP1 & 0.778 & 0.649 & 0.739 & 0.756 & 0.800 & $\mathbf{0 . 9 3 3}$ \\
WP2 & 0.492 & 0.609 & 0.641 & 0.439 & 0.474 & $\mathbf{0 . 8 9 6}$ \\
\hline
\end{tabular}

Source: Primery data processed in 2020

Table 1 shows the cross-loading values. All indicators have a higher coefficient of correlation with each of the measures themselves than a correlation coefficient with other variables. So, each of the meters is the variable constructor. The second is comparing the AVE root value of each construct with the correlation between constructs. As represented in Table II, the root value of AVE in each variable is greater than the value between constructs

Table 2. Correlation value between constructs and the square root value of AVE

\begin{tabular}{lllllll}
\hline & ATT & PBC & RC & RSI & SN & WTP \\
\hline ATT & $\mathbf{0 . 9 3 3}$ & & & & & \\
PBC & 0.615 & $\mathbf{0 . 8 1 2}$ & & & & \\
RC & 0.793 & 0.619 & $\mathbf{0 . 8 6 7}$ & & & \\
RSI & 0.886 & 0.658 & 0.814 & $\mathbf{0 . 9 0 6}$ & & \\
SN & 0.844 & 0.514 & 0.726 & 0.811 & $\mathbf{0 . 8 5 6}$ & \\
WTP & 0.709 & 0.689 & 0.759 & 0.696 & 0.714 & $\mathbf{0 . 9 1 4}$ \\
\hline
\end{tabular}

Source: Primery data processed in 2020 
The structural model was assessed with some measurements. The $\mathrm{R}^{2}$ value for ATT was 0.628 , for RSI was 0.663 , and for WTP was 0.702 . These explain that the variability of the ATT can be explained by the variability of the RC construct of $62,8 \%$, the variability of RSI can be explained by the variability of RC construct of $66,3 \%$, and WTP can be explained by the variability of RC, ATT, RSI, SN, and PBC construct of $70,2 \%$. Meanwhile, the rest is explained by other variables outside the research model.

Table 3. $F^{2}$

\begin{tabular}{llll}
\hline Path & & & $\mathrm{F}^{2}$ \\
\hline ATT & $\longrightarrow$ & WTP & 0.000 \\
PBC & $\longrightarrow$ & WTP & 0.232 \\
RC & $\longrightarrow$ & ATT & 1.690 \\
RC & $\longrightarrow$ & RSI & 1.968 \\
RC & $\longrightarrow$ & WTP & 0.164 \\
RSI & $\longrightarrow$ & WTP & 0.020 \\
SN & $\longrightarrow$ & WTP & 0.120 \\
\hline
\end{tabular}

Source: Primery data processed in 2020

The value of $\mathrm{F}^{2}$ was pointed in Table 3, where RC to ATT, RC to RSI, RC to WTP, and PBC to WTP have great F2 worth. That means they have substantial influence, whereas ATT to WTP and RSI to WTP minor impact. Another measurement is $\mathrm{Q}^{2}$. In this current research, this value was 0,963 , which is greater than zero, representing that our model has good predictive relevance. Thus, Goodness of Fit (GOF) is used to validate the overall structural model. The GOF value of this study was 0.722 . It refers to a good GOF value. The strength of the relationship between constructs and hypothesis testing can be seen from the path coefficient below.

Table 4. Path Hypothesis

\begin{tabular}{|c|c|c|c|c|c|c|}
\hline \multirow{2}{*}{$\begin{array}{l}\text { Hyphothesis } \\
\text { H1 }\end{array}$} & \multicolumn{3}{|c|}{ Relationship } & \multirow{2}{*}{$\begin{array}{l}\text { Path } \\
\text { Coefficient } \\
0.030\end{array}$} & \multirow{2}{*}{$\begin{array}{l}\text { T- } \\
\text { value } \\
0.152\end{array}$} & \multirow{2}{*}{$\begin{array}{l}\text { P- } \\
\text { value } \\
0.879\end{array}$} \\
\hline & ATT & $\rightarrow$ & WTP & & & \\
\hline H2 & SN & $\rightarrow$ & WTP & 0.369 & 2.832 & 0.005 \\
\hline H3 & PBC & $\rightarrow$ & WTP & 0.359 & 3.222 & 0.001 \\
\hline $\mathrm{H} 4$ & RSI & $\rightarrow$ & WTP & -0.193 & 1.195 & 0.233 \\
\hline H5 & $\mathrm{RC}$ & $\rightarrow$ & ATT & 0.793 & 5.744 & 0.000 \\
\hline H6 & $\mathrm{RC}$ & $\rightarrow$ & RSI & 0.814 & 8.463 & 0.000 \\
\hline H7 & $\mathrm{RC}$ & $\rightarrow$ & WTP & 0.403 & 3.479 & 0.001 \\
\hline
\end{tabular}

Source: Primery data processed in 2020

\section{The Influence of Attitude on Willingness to Pay}

According to the hypothesis test, the attitude does not influence consumer willingness to pay for halal products. This is explained by the value of $\mathrm{T}$ statistic $<\mathrm{T}$ Table; $0.152<1.96$; and P-value $>0.05 ; 0.0879>0.05$. This result confirms the finding of 
Afandi et al. (2014), who argued that attitude has a negative and insignificant impact on consumer's decision buying. Kashif et al. (2017) state that attitude does not significantly influence to intention to act. This result indicates that Muslim Consumer has a weak attitude toward a willingness to pay halal-certified product. Although respondents gave a higher appraisal in the questionnaire related to attitude aspects, they were reluctant to pay more for halal products. It can be caused by the price of a halal-certified product in Indonesia is cheap enough. Besides, it shows that consumer's willingness to pay is influenced by other factors except for attitude.

\section{The Influence of Subjective Norm on Willingness to Pay}

Based on the hypothesis test, subjective norm affects positively and significantly the willingness to pay for a halal-certified product as indicated by $\mathrm{T}$ statistic $>\mathrm{T}$ table; $2.832>1.96$, and $\mathrm{P}$ value $<0.05 ; 0.005<0.05$. Therefore the stronger person's subjective norm, the stronger the influence on willingness to pay. A Muslim student at Yogyakarta considers the importance of the impact of the subjective norm from the surrounding environment, such as family, friends, etc. If people around him including parents, family, friends, relatives, and communities give social pressure like certain perceptions then this can affect intention and behavior. This result confirms the findings of Kumar and Smith (2017), Huang et al. (2015) that subjective norm positively impacts intention to buy local food. Lada et al. (2009) also state that subjective norm affects willingness to pay.

\section{The Influence of Perceived Behavioral Control on Willingness to Pay}

This research proves that perceived behavioral control positively predisposes willingness to pay as indicated by T statistic $>\mathrm{T}$ table; 3.222 >1.96, and $\mathrm{P}$ value $<0.05$; 0.001 . This research is supported by Huang et al. (2015), who argued that perceived behavioral control has a positive relationship with the willingness to pay. Efendi et al. (2020) reveal that perceived behavioral control positively and significantly affects Muslim students' intention for buying halal food. Thus the higher a person's perceived behavioral control, the higher his willingness to pay for a halal-certified product. This also attests that perceived behavioral control strongly predicts willingness to pay a halal-certified product.

\section{The Influence of Religious Self-Identity on Willingness to Pay}

This research finding that religious self-identity has an insignificant impact on willingness to pay as indicated by $\mathrm{T}$ statistic $<\mathrm{T}$ table; $1.195<1.96, \mathrm{P}$ value $>0.05$; $0.233>0.05$. This result is in contrast to the findings of Vanany et al. (2018), Shahzad et al. (2020), and Iranmanesh et al. (2020). However, Khibran (2019) states that Muslims' self-identity negatively affects their intention to buy beef in the traditional market because they assume that the seller is Muslim and consumption of halal is familiar around them. In Indonesia, where the population is predominantly Muslim, they consider that all foods sold are halal at affordable prices unless it displays haram 
ingredients such as pork or lard clearly. Besides that, as a Muslim majority area like Yogyakarta, people consider the availability of halal food to be certain, and they also easily get halal food raw materials. However, in contrast to Muslim minority areas, food raw materials must be imported from outside the region so that the price tends to be expensive.

\section{The Influence of Religious Commitment to Attitude}

According to data analysis, religious commitment reveals a significant and positive effect on attitude. This is evidenced by T statistic $>$ T table; $5.744>1.96$ and Pvalue $<0.05 ; 0.000<0.05$. This result shows that the stronger one's religious commitment, the stronger one's attitude towards halal food. This finding is consistent with other studies, which have pointed the significant and positive influence of religious commitment on consumer's attitudes toward the halal cosmetic product (Larasari et al., 2018). When an individual studies religion and implements it to his identity, it will affect his values and behavior. Iranmanesh et al. (2020) also indicate that religious commitment significantly affects attitude to a halal product.

\section{The Influence of Religious Commitment to Religious Self-Identity}

According to data analysis, religious commitment significantly influence religious self-identity. This is evidenced by T statistic $>\mathrm{T}$ table; $8.463>1.96$ and $\mathrm{P}$-value $<0.05 ; 0.000<0.05$. In other words, the greater an individual's religious commitment, the greater his or her religious self-identity toward a halal product. This finding is supported by Iranmanesh et al. (2020), who argued that religious commitment is a strong predictor of religious self-identity for a halal product. Soesilowati (2010) states in Vanany et al. (2018) that the level of an individual's degree of religiosity will influence an individual's concern for consuming halal food. Religious self-identity itself is built by the internalization of the role of religion in providing the basis for the values of the moral life. Therefore, the influence of internalized religion on individuals who can form their own identity can be manifested in activities such as engaging in religious activities, adhering to faith, gaining spiritual, cognitive, and emotional experiences.

\section{The Influence of Religious Commitment on Willingness to Pay.}

In this research, we find that religious commitment has a positive impact on willingness to pay. It is proved by the value of T statistic $>\mathrm{T}$ table; $3.479>1.96$, and $\mathrm{P}$ value $<0.05 ; 0.001<0.05$. In another word, religious commitment strongly predicts willingness to pay for halal-certified food. It confirms the finding of Amalia et al. (2020), who explained that religiosity influences attitude and intention to buy halal food. Iranmanesh et al. (2020) state that religious commitment becomes a strong predictor for consumer's willingness to pay a halal-certified product. Therefore, the religious commitment of Muslim students in Yogyakarta affects their willingness to pay halal-certified products. 


\section{Conclusion}

This research proves that the extension of the theory of planned behavior consists of attitude, subjective norm, and perceived behavioral control is used to evaluate its impact on willingness to pay. The results of it are (1) subjective norms and perceived behavioral control significantly and positively affect the willingness to pay a halal-certified product, (2) attitude does not influence significantly on consumer's willingness to pay, (3) Religious commitment affects attitude, religious self-identity, and willingness to pay, (4) religious self-identity does not influence significantly on willingness to pay.

In terms of theoretical implications, this study is very well showing us empirical evidence of consumer behavior on willingness to pay a halal-certified product from global branded franchise restaurants with the approach of the theory of planned behavior like previous studies (Iranmanesh et al., 2020; Kashif et al., 2017; Huang et al., 2015, etc). The managerial implication of this study gives benefit for the government to more pay attention to products in society and do a survey to companies, Micro, Small and Medium Enterprises (MSME) about the food or beverage products they sell in public periodically by involving BPOM and LPPOM MUI. For enterprises and MSME, obeying the government rules of certifying halal products is a necessary factor. Nowadays, the halal product market becomes a potential market, so it can give business opportunities. Also, although religious self-identity and attitude do not have a significant effect on consumers' willingness to pay, it does not mean that the halalness of the product can be ignored. The effect of the two variables is insignificant because the majority of Muslims in Indonesia think that the products sold are all halal. Therefore, Muslim entrepreneurs must pay attention to the halal aspects of their products, from raw material and logistic process. The limitation of this study is the respondent was limited to Muslim students in Yogyakarta. So, future research can be established by doing a comparative analysis between the Muslim majority area and minority.

\section{References}

Afandi, A., Kamela, I., \& Trianita, M. (2014). Pengaruh kesadaran merek, motivasi, persepsi, dan sikap terhadap terhadap keputusan konsumen membeli mobil merek Toyota avanza di Kota Padang. E journal bunghatta.

Afrief.org. (2019/06). The Global Halal Industry: An Overview.Diakses Pada Minggu 12 Juli 2020, dari https://afrief.org/wp-content/uploads/2019/06/GLOBALHALAL-ECONOMY-REPORT.pdf

Ahmed, W., Najmi, A., Faizan, H. M., \& Ahmed, S. (2018). Consumer Behaviour towards Willingness to Pay for Halal Products: An Assessment of Demand for Halal Certification in a Muslim Country. British Food Journal, Vol. 121 No. 2, pp 492-504. https:// doi.org/10.1108/BFJ-02-2018-0085 
Aisyah, M. (2014). The Influence of Religious Behavior on Consumers' Intention to Purchase Halal-Labeled Products. Business and Entrepreneurial Review Vol. 14, No.1, pp 15-32. http://dx.doi.org/10.25105/ber.v14i1.51

Ajzen, I. (1991). The Theory of Planned Behavior. Organizational Behavior and Human Decision Processes 50, pp 179-211.

Ajzen, I., Albarracin, D., \& Hornik, R. (2007). Prediction and Change of health Behavior: Applying the Reasoned Action Approach. Lawrance Erlbaum Associates.

Ali, A., Ali, A., Xiaoling, G., Sherwani, M., \& Hussain, S. (2017). Expanding the theory of planned behaviour to predict Chinese Muslims halal meat purchase intention. British Food Journal. https://doi.org/10.1108/BFJ-05-2017-0278

Amalia, F. A., Sosianika, A., \& Suhartanto, D. (2020). Indonesian Millennials'Halal Food Purchasing: Merely A Habit? British Food Journal. https://doi.org/10.1108/BFJ-10-2019-0748

Arni, A. S., Amaliah, I., \& Riani, W. (2018). Preferensi Masyarakat Terhadap Produk Makanan Kemasan Berlabel Halal dan Tidak Berlabel Halal. (pp 17-23). Prosiding ilmu Ekonomi.

Chen, M.-F., \& Tung, P.-J. (2014). Developing An Extended Theory of Planned Behavior Model to Predict Consumers' Intention to Visit Green Hotels. International Journal of Hospitality Management, pp 221-230. https://doi.org/10.1108/APJML-08-2017-0168

Efendi, R., Sukidjo, \& Bahrun, K. (2020). Faktor-Faktor Niat Membeli Makanan Berlabel Halal pada Mahasiswa Muslim Yogyakarta. Jurnal Ilmiah Ekonomi Islam 6 (01), pp 70-79. http:/ / dx.doi.org/10.29040/jiei.v6i1.514

Ekonomibisnis.com. (16 Januari 2019). LPPOM UI: Baru 668.615 Produk di Indonesia Terserifikasi Halal. Diakses pada 15 Juli 2020, dari https://ekonomi.bisnis.com/read/20190116/12/879298/lppom-ui-baru668.615-produk-di-indonesia-tersertifikasi-halal

Fathi, E., Zailani, S., Iranmanesh, M., \& Kanapathy, K. (2016). Drivers of Consumers'Willingness to Pay for Halal Logistics. British Food Journal Vol. 118 No. 2, pp 464-479. https:/ / doi.org/10.1108/BFJ-06-2015-0212

Haryono, S. (2016). Metode SEM Untuk Penelitian Manajemen dengan AMOS 22.00, LISREL 8.80 dan Smart PLS 3.0. Bekasi: PT. Intermedia Personalia Utama.

Hidayat, R., \& Akhmad, S. (2015). The Influence of Service Quality, Religious Commitment and Trust on The Customers'Satisfaction and Loyalty and Decision to do The Transaction in Mnadiri Sharia Bank of Jawa Timur. Al-Ulum, pp 57- 90.

Huang, L.-F., Chiang, C.-C., \& Chen, H.-C. (2015). Willingness to Pay of Visitors for the Nature-based Public Park: An Extension of Theory of Planning Behavior (TPB). Journal of Information and Optimization Sciences, pp 405-429. https://doi.org/10.1080/02522667.2014.903701

Hultman, M., Kazeminia, A., \& Ghasemi, V. (2015). Intention to Visit and Willingness to Pay Premium for Ecotourism: The Impact of Attitude, Materialism, and 
Motivation. Journal of Business Research, pp 1-8. https:// doi.org/10.1016/j.jbusres.2015.01.013

Iranmanesh, M., Mirzaei, M., Hosseine, S.M., \& Zailani, S. (2020). Muslims' Willingness to Pay for Certified Halal Food: An Extension of The Theory of Planned Behavior. Journal of Islamic Marketing, pp 14-30.

Kadengkang, J. A., \& Linarti, U. (2020). Pengukuran Perilaku dan Niat Beli Produk Kosmetik Halal Melalui Modifikasi Theory of Planned Behavior (TPB). Jurnal Ilmiah Psikologi Terapan, pp 19-25. http:// ejournal.umm.ac.id/index.php/jipt/

Kashif, M., Zarkada, A., \& Thurasamy, R. (2017). The moderating effect of religiosity on ethical behavioural intentions: An application of the extended theory of planned behaviour to Pakistani bank employees. Personal Review, pp 429-448. https:// doi.org/10.1108/PR-10-2015-0256

Kautonen, T., Gelderen, M. V., Fink, M., \& Kepler, J. (2015). Robustness of The Theory of Planned Behavior in Predicting Entrepreneurial Intentions and Actions. Entrepreneurship Theory and Practice Volume 39, Issue 3, pp 655-674. https://doi.org/10.1111/etap.12056

Khibran, M. (2019). An Investigation toward Purchase Intention of Halal Beef from Traditional Market: A TPB Perspective. Asian Journal of Islamic Management (AJIM), pp 1-12. https://doi.org/10.20885/ajim.vol1.iss1.art1

Kim, Y. G., Woo, E., \& Nam, J. (2018). Sharing economy perspective on an integrative framework of the NAM and TPB. International Journal of Hospitality Management, pp 109-117. https:// doi.org/10.1016/j.ijhm.2018.01.008

Kontan.co.id. (13 September 2019). Geliat Bisnis Waralaba di Indonesia Mulai Bangkit Kembali. Diakses pada Minggu, 27 September 2020, dari https:// peluangusaha.kontan.co.id/news/geliat-bisnis-waralaba-diindonesia-mulai-bangkit-kembali?page $=$ all

Kumar, A., \& Smith, S. (2017). Understanding Local Food Consumers: Theory of Planned Behavior and Segmentation Approach. Journal of Food Products Marketing, pp 1-20. https://doi.org/10.1080/10454446.2017.1266553

Lada, S., Tanakinjal, G. H., \& Amin, H. (2009). Predicting Intention to Choose Halal Products Using Theory of Reasoned Action. International Journal of Islamic and Middle Eastern Finance and Management, pp 1753-8394. https://doi.org/10.1108/17538390910946276

Larasati, A., Hati, S. R., \& Safira, A. (2018). Religiusitas dan Pengetahuan Terhadap Sikap dan Intensi Konsumen Muslim untuk Membeli Produk Kosmetik Halal. Jurnal Bisnis dan Manajemen Volume 8 (2), pp 105-114. https:// doi.org/10.15408/ESS.V8I2.7459.

Maharani, N. K., \& Silvia, A. (2019). Analisis Pengaruh Pengetahuan dan Religiusitas terhadap Niat Pembelian Produk Kosmetik Halal. Al Urban: Jurnal Ekonomi Syariah dan Ekonomi Islam, pp 81-94. https://doi.org/10.22236/alurban_vol3/is2pp1-11

Mothersbough, D. L., \& Hawkins, D. I. (2016). Connsumer Behavior Building Marketing Strategy (13st ed.). New York: McGraw-Hill Education. 
Newaz, F. T., Fam, K. S., \& Sharma, R. S. (2016). Muslim Religiosity and Purchase Intention of Different Categories of Islamic Financial Products. Journal of Financial Services Marketing, pp 141-152. https:// doi.org/10.1057/fsm.2016.7

Ngah, A. H., Gabarre, S., Eneizan, B., \& Asri, N. (2020). Mediated and moderated model of the willingness to pay for halal transportation. Journal of Islamic Marketing, pp 1-21. https:// doi.org/10.1108/JIMA-10-2019-0199

Rahman, A. A., Asrarhaghighi, E., \& Rahman, S. A. (2015). Consumers and Halal Cosmetic Products: Knowledge, Religiosity, Attitude and Intention. Journal of Islamic Marketing Vol. 6 No. 1, pp 148-163. https://doi.org/10.1108/JIMA-09$\underline{2013-0068}$

Republika.co.id. (28 Juni 2019) Kesadaran halal konsumen-produsen UKM masih rendah. Diakses pada Senin, 28 September 2020, dari https://republika.co.id/berita/ekonomi/korporasi/ptsonl370/kesadaranhalal-konsumenprodusen-ukm-masih-rendah

Salaamgateaway.com. (2019/20). State of the Global Islamic Economy Report. Diakses Pada MInggu 12 Juli, dari https:// www.salaamgateway.com/SGIE19-20

Shahzad, M. A., Jun, D., Noor, G., \& Zubair, A. (2020). Causation of halal food consumption in China. Journal of Islamic Marketing. https://doi.org/10.1108/JIMA-07-2019-0153

Soesilowati, E. S., \& Yuliana, C. I. (2013). Komparasi Perilaku Konsumen Produk Halal di Area Mayoritas dan Minoritas Muslim. Jurnal Ekonomi dan Pembangunan Vol 21, No. 2, pp 167-178. https:// doi.org/10.14203/JEP.21.2.2013.49-60

Syahputra, A., \& Hamoraon, H. D. (2014). Pengaruh Labelisasi Halal Terhadap Keputusan Masyarakat Kecamatan Perbaungan Dalam Pembelian Produk Makanan Dalam Kemasan. Jurnal Ekonomi dan Keuangan Vol.2 No.8, pp 475-487.

Syahrir, Danial, Yulinda, E., \& Yusuf, M. (2020). Aplikasi Metode SEM-PLS dalam Pengelolaan Sumberdaya Pesisir dan Lautan. Bogor: Penerbit IPB Press

Vanany, I., Soon, J. M., Maryani, A., \& Wibawa, B. M. (2018). Determinants of Halal Food Consumption in Indonesia. Journal of Islamic Marketing. https:// doi.org/10.1108/JIMA-09-2018-0177

Verma, V. K., \& Chandra, B. (2017). An Application of Theory of Planned Behavior to predict Young Indian Consumers'Green Hotel Visit Intention. Journal of Cleaner Production, pp 1-11. https:// doi.org/10.1016/i.jclepro.2017.10.047

Weaver, G. R., \& Agle, B. R. (2002). Religiosity and Ethical Behavior in Organizations: A Symbolic Interactionist Perspective. Academy of Management Review Vol. 27, No.1, pp 77-97.

Wong, S. L., Hsu, C. C., \& Chen, H. S. (2018). To Buy or Not to Buy? Consumer Attitudes and Purchase Intentions for Suboptimal Food. International Journal of Environmental Research and Public Health, pp 1-13. https://doi.org/10.3390/ijerph15071431

Zhang, M., \& Bockstedt, J. (2020). Complements and Substitutes in Online Product Recommendations: The Differential Effects on Consumers' Willingness to Pay. Information \& Management. https:// doi.org/10.1016/j.im.2020.103341 